\title{
EDITORIAL
}

\section{What We Talk About When We Talk About Students as Partners}

\author{
*Alison Cook-Sather ${ }^{a}$, Kelly E. Matthews ${ }^{b}$, Anita Ntem ${ }^{c}$ and Sandra Leathwick ${ }^{b}$ \\ aTeaching and Learning Institute, Bryn Mawr College, USA \\ bInstitute for Teaching and Learning Innovation, The University of Queensland, Australia \\ ${ }^{c}$ Charter Management Office, Democracy Prep Public Schools, USA
}

Contact: acooksat@brynmawr.edu

Many authors have borrowed the title of Raymond Carver's collection of short stories, What We Talk About When We Talk About Love, to frame their explorations of everything from hip hop to running to games. Like Carver and those who have echoed him, we want to surface the multiple dimensions that are integral to our, as to any, complex subject. We acknowledge that the terms used to capture that complexity carry with them intended and unintended associations (such as those with Carver himself). In reference to "students as partners," not only the explicit what and when but also the implicit why can evoke a variety of associations and reactions. A single short story among many, this editorial is one installment in a series of ongoing discussions of what we talk about when we talk about "students as partners."

We, in this case, are two students and two academics/faculty working in partnership as four (of a total of eight) co-editors who intentionally chose the term "students as partners" for this journal's name. Our goals in attempting to unpack this term are to acknowledge and to invite further dialogue about the variety of reactions the term provokes and to move us toward developing generative theories of partnership praxis (Matthews et al., in 2018a). The term aims to capture an aspiration for working together in higher education in a way that rejects traditional hierarchies and assumptions about expertise and responsibility. However, by naming only one participant in the partnership and not specifying the nature of that partnership, the term can evoke associations and feelings that undermine that aspirational aspect. For these and other reasons, some practitioners and scholars might prefer to use whatever term suits their local context, letting, as IJSAP Advisory Board and faculty member Peter Felten puts it, "a thousand flowers bloom with the naming of this (widely varied and highly contextual) practice" (personal communication, August 9, 2018). But as "an umbrella term" (Healey, Flint, \& Harrington, 2014) with wide recognition, "students as partners" can create a community of practitioners and scholars committed to working together through partnership in higher education. 
Drawing on our own perspectives as co-authors and those of critical friends who are members of the journal's editorial and advisory boards, we explore the emergence of the term, the explicit naming of "students" in "students as partners," and the ways that the other words in the term-"as" and "partners" - signal different things to people in different positions and contexts. Our goal is not to argue reductively about definitions and practices associated with the term "students as partners"; instead, our hope is that this editorial, and this journal more generally, can at once affirm, challenge, and, in some cases, change the discourse around how the term "students as partners" is used, and promote a particular, values-based perspective on its use (Cliffe et al., 2017) that enables the creative translation of partnership principles across an array of practices. Throughout this editorial we higlight components of the term we are exploring in quotation marks (i.e., "students," "as," "partners," and "students as partners") and do not use any acronyms (e.g., SaP) to keep the components of the term, the relationships among them, and the entire term itself the focus of attention.

\section{THE EMERGENCE OF THE TERM "STUDENTS AS PARTNERS"}

The term "students as partners" emerged in response to a felt need to name students as colleagues - to call into presence and action a constituency in higher education traditionally considered the recipient, not the producer, of knowledge (Neary, 2010). One of the earliest uses of the term articulated clearly that "the vision of learner as passive consumer is inimical to a view of students as partners with their teachers in a search for understanding" (Ramsden, 2008, p. 16). As Cherie Woolmer, staff member and Managing Editor of IJSaP, notes (personal communication, August 10,2018), the concept of "students as partners" was part of a counter discourse to Student Engagement policy drives in the United Kingdom and recognised "that all members in the partnership have legitimate, but different, perceptions and experiences" (Quality Assurance Agency [QAA], 2012). In the United States, Mihans, Long, and Felten (2008) used the term "students as partners" to describe their approach in one of the first course redesign projects.

Since these early namings of "students as partners" and partnership as an alternative to more traditional hierarchical relationships, numerous scholars have argued that positioning students in partnership with academics, or staff more broadly (e.g., administrators, librarians, professional staff), challenges a growing conception of students as customers or consumers and offers a counter-narrative to transactional and dehumanising, business-oriented rhetoric influencing higher education (Cook-Sather \& Felten, 2017; Healey, Flint, \& Harrington, 2014; Matthews, Dwyer, Hine, \& Turner, 2018). Some people use the term "students as partners" to signal this work; others use the terms "student-staff partnership" or "student-faculty partnership," naming both participants; and still others use terms such as "co-creating learning and teaching" (Bovill, Cook-Sather, Felten, Millard, \& Moore-Cherry, 2016), naming neither participant. (See Matthews et al., 2018a for a discussion of the most common terms used and the interpretive framing they signal.)

Choices around such naming parallel a similar phenomenon in primary and secondary educational contexts, captured for many scholars and practitioners by an equally contested term: "student voice." This term aims to signal not only the literal sound of students' words as they inform educational planning, research, and reform but also the collective contribution of 
diverse students' presence, participation, and power in those processes (Cook-Sather, 2002, 2006; Fielding, 2001; Rudduck \& Flutter, 2004; see Bourke \& Loveridge, 2018, for a more recent discussion). Likewise, students-as-partners work "challenges traditional assumptions about the identities of, and relationships between, learners and teachers" and "imagines and makes way for respectful, mutually beneficial learning partnerships where students and staff work together on all aspects of educational endeavours" (Matthews, 2017, p. 1).

As terms, both "student voice" and "students as partners" question the roles of complacency and compliance in classrooms to which students are typically assigned and also offer a constructive way of thinking about the power and agency students can have. For many who do partnership work, using the term "students as partners" is a way of recognising who gets to shape higher education: "As \#highered we are still in a place where we do not realize that students are central to what we do. Anytime our decisions are made with them as an afterthought we are heading down a wrong path" (Will, 2018).

Like "student voice," the term "students as partners" and the various and complex reactions it provokes challenge us to remain conscious and intentional in the ways we work together and the words we use to name that work. However, the terms can be appropriated and used in ways that are "cynical and manipulative" (Fielding, 2004, p. 200) and actually counter the spirit embraced by those who developed them. As Senior Editor of IJSaP Mick Healey reminds us (personal communication, August 5, 2018), senior management, governments, and some scholars (and even some practitioners) can misappropriate the term to describe a consumerist, neo-liberal approach to student engagement (Dwyer, 2018; M. Healey \& R. L. Healey, 2018; M. Healey, R. L. Healey \& Cliffe, 2018).

Continuously reflecting on and talking about the why of engaging in partnership work should always be in conversation with the what, when, who, and how of "students-as-partners" practices.

\section{THE POWER IN NAMING AND BEING NAMED}

To name is to bring into being (Cook-Sather, Bahti, \& Ntem, in preparation, 2018; CookSather, Matthews, Acai, M. Healey, \& R. L. Healey, in preparation, 2018; Van Manen, McClelland, \& Plihal, 2007). Both "student voice" and "students as partners" name students to signal the inclusion of a group of people traditionally excluded from educational analysis and practice. Academics/faculty have typically possessed-and often continue to possess-sole agency and authority in conceptualising, designing, implementing, evaluating, and researching educational practices in higher education. Naming students as partners signals that a change in educational cultures and practices would have to start with those in positions of power. Consequently, student co-author Sandra Leathwick sees the invitation that the term extends as an important starting point to truly rethink power in relationships between learners and teachers.

However, while there are benefits to naming those who have not typically been afforded agency and recognition in higher education, naming only one participant in the term "students as partners" assumes academics/faculty, or staff more broadly, do not need to be named. Thus, by mentioning only students, the term can be at odds with the principles of reciprocity that define the notion of partnership (Cook-Sather, Bovill, \& Felten, 2014; Cook- 
Sather \& Felten, 2017) and are central to power sharing in partnership praxis (Matthews, 2017). Furthermore, as IJSaP student co-editor Rachel Guitman notes, in naming only students, the term lends itself to tokenistic inclusion of students and generally tokenistic understandings of the practices the term aims to signal (personal communication, August 12, 2018). Thus, those with the power to name can also appropriate the language, particularly where the principles of partnership-entangled with power and identity-are not valued or understood as complex relational work. For these reasons, the term falls short in relation to practice in which "mutuality, reciprocity, and complementarity are of key importance in the relationship between student and teacher" (Hermsen, Kuiper, Roelofs, \& van Wijchen, 2017, p. 3).

Student-staff partnership practices seek to rethink and share power in new ways through ongoing dialogue and reflection. When students work as colleagues with other students, academics/faculty, or staff more broadly, the shift they experience in traditional power dynamics can make the term "students as partners" feel contradictory or constraining. Consistent with standpoint theory, not being named in "students as partners" suggests that the speaker is not a student, which could imply lack of agency and authority to name the practice of partnership. This implication emerges because the term itself, at first an invitation to be included, changes in meaning as partnerships progress. It becomes a reminder to those involved that academics/faculty have had the power to say that students are partners and to initiate such practices. The rationale to name students specifically-as an act of radical inclusion - can become an act of exclusion as the aspirations of partnership are realised.

Rethinking and sharing power do not eliminate power dynamics among participants with different positions and identities; power and identity are always central to partnership practices (Matthews et al., 2018a). However, rather than conceptualising power as a finite resource that students and academics or staff compete for and that one group wields over another, scholars have positioned power as an evolving human creation that can be understood, shared, shaped, reimagined, and transformed through dialogue in partnership (Cates, Madigan, \& Reitenauer, 2018; Cook-Sather, Felten, \& Bovill, 2014; Kehler, Verwoord, \& Smith, 2017; Matthews, 2017). As student co-author Anita Ntem argues, the term "students as partners" is an imperfection that invites us into different ways of working together in higher education and provokes us to see ourselves and our positions in higher education differently. Being comfortable with the uncomfortable juxtaposition between invitation and provocation that the term embodies can allow for the expression of fluid identities and the reshaping of power within the social relationships that define partnership.

\section{TERMS IN AND ACROSS CONTEXT: ENABLING AND CONSTRAINING HOW WE SEE OURSELVES AND HOW WE ACT IN PARTNERSHIP}

The importance of fluidity that we note in the previous section increases as we consider how to name and enact partnership work across contexts where people speak different languages and embrace different cultures. The words "as" and "partners," sometimes more than the word "students," pose challenges of translation across contexts and are interpreted differently in different cultural and socio-political contexts.

The "as" in the term names only one dimension of one participant's identity, which feels reductive to some. Students in both the United States and Australia have talked about how the 
"as" makes them feel that the partnership identity is partial or temporary or otherwise not integrated with who they are. While being named "as" a partner can influence self and peerperceptions, the broader conception of partnership implied in "students as partners" can also be troublesome. Thus, the overall effect of the term causes some people to feel excluded.

The word "partner" means different things depending on which part of the world you come from, and the term "students as partners" does not signal the nature of the partnership. Student co-author Anita notes that at the 2018 International Students as Partners Institute, some participants associated the term "partner" with a business relationship -a transactional play on a power-driven relationship. Gläser highlighted this issue in her discussion of how to decide what language to use to name emerging partnership practices in the context of higher education in Germany (Cook-Sather, Woolmer, Gläser, \& Felten, 2018), noting that the term "partners" in Germany is likely to signal sexual partners (and plenty of people whose first language is English have had the same reaction). IJSaP co-editor and faculty member Ruth Healey (personal communication, August 13, 2018) discovered through conversation with international colleagues that those in The Netherlands share the German interpretation, whereas in France "partnership" evokes the business relationship Anita mentioned. And in the context of Aotearoa New Zealand, faculty co-author Alison Cook-Sather learned that the term "partnership" can signal disenfranchisement by evoking what many Māori experience as failed promises made by the British Crown traced back to the Treaty of Waitangi, the founding document of the country (Cook-Sather, in press; Berryman, Bourke, \& Cook-Sather, in preparation, 2018).

Thus, what terms mean to different people in different places is a critical aspect to consider when thinking of ways to convey the essence of this work. Not only is the work that is signalled by the term "students as partners" context dependent (M. Healey \& R. L. Healey, 2018) in both how it is introduced and in how it is interpreted, but also the meanings of the entire term and its constituent parts are culturally and linguistically dependent, and differences across cultural contexts set the tone for how the work will be perceived and experienced.

\section{ONGOING DIALOGUE AT THE INTERSECTION OF PRACTICE AND THEORY}

The language of the term "students as partners" prompts people to analyse their assumptions and reactions and try to access what those are based on. As faculty co-author Kelly Matthews argues, struggles around what to call this work are deeper than the level of language, of terminology: they are the result of wrestling with the intentionality of the construct of partnership, the challenge it poses regarding assumptions about the relationships between learners and teachers, and how these assumptions interact with the structure and hierarchy of educational systems. What really matters are the underlying values and principles of studentsas-partners work and how these are translated into practice and then reflected upon to refine both our thinking and our practices. Therefore, whether embracing or struggling with the term, all can experience "students as partners" as a link to an array of practices and a diversity of people in a broader, international community. Working with, through, and against such a term can be a process of community building through dialogue, and the language will evolve if the international movement toward embracing partnership is successful. 
Whatever we call this work, questions will remain about its premises and how the work can unfold within traditional institutional structures and dynamics. For example, a recent twitter reply to a comment contesting the term "students as partners" demonstrates how the aspiration of efforts to disrupt traditional identity roles and power structures can be challenged: "Interesting this notion finally gets some play. 'Partners' implies parity and equal status and \#studentsaspartners often has a pretentious, misleading, flavour. It denies the very real differences between faculty and students. Don't disguise your position of power" (Wright, 2018). While to our minds, as we discussed above, rethinking and sharing power do not eliminate power dynamics among participants with different positions and identities, the term "students as partners" can seem to claim that it does.

We will have to continue discussing what the words mean to whom, when, and in what context. In our effort to disrupt taken-for-granted cultural norms often operating invisibly in higher education, it is not possible to reduce into a single, easily understood phrase that translates across context, countries, and cultures the complexity of the constructs student, partner, and partnership as they interact with the constructs of power and identity. While we acknowledge the appeal of finding the right name, our collective experiences suggest that affirming the complexity of the work of partnership across power differences and fluid identities of people in higher education is hard, and practice and theorising will always be an important focus of ongoing debate, contestation, and conversation. We all concur with student co-author Anita that the practices of partnership will always be more complex than the words we use to describe them.

\section{ACKNOWLEDGEMENTS}

Many thanks to Sophia Abbot, Peter Felten, Rachel Guitman, Mick Healey, Ruth Healey, Liz Ho, and Cherie Woolmer who offered inspiring insights and helpful guidance as we developed this editorial.

\section{NOTE ON CONTRIBUTORS}

Alison Cook-Sather is the Mary Katharine Woodworth Professor of Education at Bryn Mawr College and Director of the Teaching and Learning Institute at Bryn Mawr and Haverford Colleges, United States.

Kelly E. Matthews is an Associate Professor of Higher Education at The University of Queensland in Brisbane, Australia, and an Australian Learning \& Teaching Fellow.

Anita Ntem is a recent graduate of Bryn Mawr College, where she was a student partner and researcher in the SaLT program through the Teaching and Learning Institute, and she is currently the Special Assistant to the Superintendent at Democracy Prep Public Schools, United States.

Sandra Leathwick is a PhD student at The University of Queensland and a Lecturer at the Australian Catholic University, both in Brisbane, Australia. 


\section{REFERENCES}

Berryman, M., Bourke, R., \& Cook-Sather, A. (in preparation, 2018). Weaving mana ōrite, ako, and pedagogical partnership principles: Understanding partnership in education within and beyond Aotearoa New Zealand. Manuscript in preparation.

Bourke, R., \& Loveridge, J. (Eds.) (2018). Radical collegiality through student voice: Educational experience, policy and practice. Springer Singapore.

Bovill, C., Cook-Sather, A., Felten, P., Millard, L., \& Moore-Cherry, N. (2016). Addressing potential challenges in co-creating learning and teaching: Overcoming resistance, navigating institutional norms and ensuring inclusivity in student-staff partnerships. Higher Education, 71(2), 195-208.

Cates, R., Madigan, M., \& Reitenauer, V. (2018). 'Locations of Possibility': Critical perspectives on partnership. International Journal for Students as Partners, 2(1), 33-46. https://dx.doi.org/10.15173/ijsap.v2i1.3341

Cliffe, A., Cook-Sather, A., Healey, M., Healey, R. L., Marquis, E., Matthews, K. E., MercerMapstone, L., Ntem, A., Puri, V., \& Woolmer, C. (2017). Launching a journal about and through students as partners. International Journal for Students as Partners, 1(1).

Cook-Sather, A. (2002). Authorizing students' perspectives: Toward trust, dialogue, and change in education. Educational Researcher, 31(4) 3-14.

Cook-Sather, A. (2006). Sound, presence, and power: Exploring "student voice" in educational research and reform. Curriculum Inquiry, 36(4), 359-390. Retrieved from https://www.jstor.org/stable/4124743

Cook-Sather, A. (in press). Perpetual translation: Conveying the languages and practices of student voice and pedagogical partnership across differences of identity, culture, position, and power. Transformative Dialogues.

Cook-Sather, A., Bahti, M., \& Ntem, A. (in preparation, 2018). Student-faculty pedagogical partnerships focused on classroom teaching and curriculum design and redesign: $A$ how-to guide for program directors, faculty, and students. Manuscript submitted for publication.

Cook-Sather, A., Bovill, C., \& Felten, P. (2014). Engaging students as partners in learning and teaching: A guide for faculty. San Francisco, CA: Jossey-Bass.

Cook-Sather, A., \& Felten, P. (2017). Ethics of academic leadership: Guiding learning and teaching. In Frank Wu \& Margaret Wood (Eds.), Cosmopolitan perspectives on becoming an academic leader in higher education (pp. 175-191). London: Bloomsbury Academic.

Cook-Sather, A., Woolmer, C., Gläser, K., \& Felten, P. (2018, June). Valuing different voices: Strategies for enacting pedagogical partnerships in diverse contexts. International Consortium for Educational Development Conference. Atlanta, GA.

Cook-Sather, A., Matthews, K. E., Acai, A., Healey, M., \& Healey, R. (in preparation, 2018). Bringing 'partnership' into being: The language and terminology of students as partners in higher education. Manuscript in preparation. 
Dwyer, A. (2018). Toward the formation of genuine partnership spaces. International Journal for Students as Partners, 2(1), 11-15. https://doi.org/10.15173/ijsap.v2i1.3503

Fielding, M. (2001). Students as radical agents of change. Journal of Educational Change, 2(3), 123-141.

Fielding, M. (2004). 'New wave' student voice and the renewal of civic society. London Review of Education, 2(3), 197-217.

Healey, M., Flint, A., \& Harrington, K. (2014). Students as partners in learning and teaching in higher education. York: Higher Education Academy. Retrieved from https://www.heacademy.ac.uk/system/files/resources/engagement through partnership . $\mathrm{pdf}$

Healey, M., \& Healey, R. L. (2018). 'It depends': Exploring the context-dependent nature of students as partners. International Journal for Students as Partners, 2(1), 1-10. https://dx.doi.org/10.15173/ijsap.v2i1.3472

Healey, M., Healey, R. L., \& Cliffe, A. (2018). Engaging in radical work: Students as partners in academic publishing. Efficiency Exchange. Retrieved from

http://www.efficiencyexchange.ac.uk/12775/engaging-radical-work-students-partnersacademic-publishing/

Hermsen, T., Kuiper, T., Roelofs, F., \& van Wijchen, J. (2017). Without emotions, never a partnership! International Journal for Students as Partners, 1(2), 1-5. https://dx.doi.org/10.15173/ijsap.v1i2.3228

Kehler, A., Verwoord, R., \& Smith, H. (2017). We are the process: Reflections on the underestimation of power in students as partners in practice. International Journal for Students as Partners, 1(1), 1-15. https://dx.doi.org/10.15173/ijsap.v1i1.3176

Matthews, K. E. (2017). Five propositions for genuine students as partners practice. International Journal for Students as Partners, 1(2), 1-9. https://dx.doi.org/10.15173/ijsap.v1i2.3315

Matthews, K. E., Cook-Sather, A., Acai, A., Dvorakova, S. L., Felten, P., Marquis, E., \& MercerMapstone, L. (2018a). Toward theories of partnership praxis: An analysis of interpretive framing in literature on students as partners in university teaching and learning. Higher Education

Research \& Development. https://doi.org/10.1080/07294360.2018.1530199

Matthews, K. E., Dwyer, A., Hine, L., \& Turner, J. (2018). Conceptions of students as partners. Higher Education, 1-15. Retrieved from https://dx.doi.org/10.1007/s10734-018-0257-y

Matthews, K. E., Mercer-Mapstone, L., Dvorakova, S. L., Acia, A., Cook-Sather, A., Felten, P., Healey, M., Healey, R., \& Marquis, E. (2018b). Enhancing outcomes and reducing inhibitors to the engagement of students and staff in learning and teaching partnerships: Implications for academic development. International Journal for Academic Development. https://doi.org/10.1080/1360144X.2018.1545233

Mihans, R. J. II, Long, D. T., \& Felten, P. (2008). Power and expertise: Student-faculty collaboration in course design and the scholarship of teaching and learning. International Journal for the Scholarship of Teaching and Learning, 2(2), Article 16. Retrieved from http://digitalcommons.georgiasouthern.edu/ij-sotl/vol2/iss2/16 
Neary, M. (2010). Student as producer: A pedagogy for the avant-garde? Learning Exchange, $1(1)$.

Quality Assurance Agency, United Kingdom. (2012). UK quality code for higher education: Part B: Assuring and enhancing academic quality: Chapter B5: Student engagement. Retrieved from https://www.qaa.ac.uk/quality-code/the-existing-uk-quality-code/part-b-assuringand-enhancing-academic-quality

Ramsden, P. (2008). The future of higher education: Teaching and the student experience. London: BIS.

Rudduck, J., \& Flutter, J. (2004). How to improve your school: Giving pupils a voice. London: Continuum Press.

Van Manen, M., McClelland, J., \& Plihal, J. (2007). Naming student experiences and experiencing student naming. In D. Thiessen \& A. Cook-Sather (Eds.) International handbook of student experience in elementary and secondary school (pp. 85-98). New York, NY: Springer.

Will, L. [DrLetitiaWill]. (2018, April 15). As \#highered we are still in a place where we do not realize that students are central to what we do. Anytime our decisions are made with them as an afterthought we are heading down a wrong path. \#Students \#studentsaspartners \#studentcentered [Tweet]. Retrieved from https://twitter.com/drletitiawill/status/985227680638492673?s=12

Wright, A. [wrightetal]. (2018, March 29). Interesting this notion finally gets some play. "Partners" implies parity and equal status and \#studentsaspartners often has a pretentious, misleading, flavour. It denies the very real differences between faculty and students. Don't disguise your position of power. [Tweet]. Retrieved from https://twitter.com/wrightetal/status/979312833996476416 